CIRR XXIII (79) 2017, 73-102

ISSN 1848-5782

UDC 327.82:796.032.2

DOI 10.1515/cirr-2017-0015

\title{
Olympic Diplomacy and the Emerging States: Striving for Influence in the Multipolar World
}

Đana Luša

\section{Abstract}

The world of sports is a reflection of the world of politics. It is becoming increasingly multipolar with the emerging states hosting mega sporting events. Firstly, the article problematizes the concept of multipolarity and, secondly, globalisation by questioning whether the Olympic Games reinforce national identities and promote national interests by using Olympic diplomacy as a soft power tool. In doing so, the article explores the correlation between the changes in international affairs and the hosting of and participation at the Olympic Games by emerging states such as Brazil, China and Russia. The analysis distinguishes globalisation from the role of the nation-state, by highlighting the evident differences between emerging states in terms of hosting the Games, but also takes into consideration geopolitical and geo-economic parameters.

\section{KEY WORDS:}

Olympic Games, Olympic diplomacy, soft power, emerging states, globalization, multipolarity 


\section{Introduction}

This article aims to highlight the shift in contemporary international affairs, in which more states present themselves as active participants, and where emerging states enjoy an influence beyond their immediate region. They do this by challenging the dominance of "old" great powers. However, there are different interpretations of the current state of affairs. According to Gratius (2008: 1), there are three general tendencies: a new international order being simultaneously uni- and multipolar; the rise of Asian countries, namely India, China and Japan; and the (re) enforcement of the nation, state and religion. This increasingly multipolar world might be strongly correlated with the influence of "[A]sianisation in the economy and consequently in the political power" (Kurečić and Kampmark 2016: 91). Furthermore, they predict that the rise of contender states will be increasingly greater than the rise of dominant states. This will keep feeding into the right circumstances for the creation of a "truly multipolar world in the first half of the 21 st century" (ibid).

The article argues that a multipolarity is emerging not only in international relations, but also in the hosting of the Olympic Games (see more in: Grix and Lee 2013: 3). For the most part, International Relations (IR) did not ignore the relevance of hosting the Games, which is also the main focus of this article. Particularly, there has been a lot of research exploring the economics behind the organisation of major sporting events (McBride 2016; Brunet and Xinwen 2008, Osada et al. 2016, Preuss 2004, Baade and Matheson 2015). Although sport does not represent the most frequent research interest among IR scholars, with its global outreach and the impact on international relations and a state's soft power, there has been an increase in the number of works focusing on the relationship between sports and politics (Houlihan 1994, Levermore and Budd 2004; Allison 1986, Allison 1993, Arnaud and Riordan 1998, Riordan and Krüger 1999). This article contributes to this trend by analysing emerging states' Olympic diplomacy as a soft power tool in the multipolar world.

The first question to address when speaking about the role of the Olympics Games is why they are being used as a case study to explore the concept of multipolarity? It is primarily because the Olympics represent the biggest 
sporting event in the world, while the outreach of the Games and the International Olympic Committee (IOC) into areas outside of sport is unmatched. "The Games symbolise one of the largest single gatherings of humans, sporting games, festivals, rituals and grand spectacle all wrapped in one intense, colourful and often controversial extravaganza" (Kelly in Kelly and Brownell 2011: 1), while the IOC with its status presents itself as a diplomatic actor in the international community. The article therefore argues that by hosting and participating at the Olympics, and by using Olympic diplomacy, emerging states may signal future opportunities of enhancing their agency in global multipolar affairs (Grix and Lee 2013).

The article addresses several issues: first and foremost, the reasons behind using Olympic diplomacy and the bidding of emerging states to host the Olympic Games are questioned; as well as what this phenomenon says about the significance of the Games and the shift in the international order. Is there a correlation between hosting the games by the emerging states and the multipolarity of international affairs? Secondly, the article will try to answer whether nation-states still play a strong role in trying to use Olympic diplomacy to promote their particular interests and strengthen their national identity in the globalised world (considering their success in hosting and participating at the Games). The article explores cases in which three BRICS states hosted the Olympic Games: China in 2008, Russia in 2014, and Brazil in 2016.

The main hypotheses are the following:

- Although mega sporting events represent cultural, economic and political phenomena considered as "main contributors to the unifying process of globalization" (Koorep 2016), sport is never detached from the concept of nation. This means that the Olympic Games and Olympic diplomacy contribute to the heterogeneous side of globalisation by reinforcing national sentiment, nationalist ideas and identities, particularly in the case of emerging states.

- The world is becoming increasingly multipolar, which is mirrored in the hosting of mega sporting events being awarded to emerging countries. Using Olympic diplomacy and winning the bidding process for the Olympics sends out a signal of change in the international community. 


\section{( Theoretical framework}

To define the structure of current international affairs, one needs to start with the term 'polarity'. "Polarity is a distribution of power among actors in the international system" (Toje 2010: 7). According to Mearsheimer (2001: 4) "unipolarity is a system with only one great power, which needs to be able to put up a 'serious fight' against the leading state". Monteiro (2014: 8) argues that the international system will remain unipolar, "as long as the United States remain the only state with substantial global power capacity, or as long as Beijing chooses not to use its resources to develop a superpower's military capability." Multipolarity, on the other hand, refers to a "[d] istribution of power in which more than two powers have comparable amounts of military, cultural and economic influence". It is characterised by the absence of supranational organising principles (Toje 2010: 7).

According to Buzan's (2004: 69) prediction, the United States (US) "has been the only superpower and there are no other candidates on the horizon for that status for at least a couple of decades." In his work he coded Russia, China, Japan and the European Union as great powers. On the other hand, many authors argue that with the shift towards multipolarity, a singular category of a "superpower" and emerging powers are defining a new plural category, that of "great powers". This new category could potentially consist of countries such as the US, China, India, Japan, Russia and the European Union. According to Cooper and Alexandroff (2010: 2), multipolarity emerges from several shifts within the contemporary global order. Firstly, the US dominated liberal international order is being seriously challenged. Secondly, international institutions are facing a fundamental crisis of efficiency. Thirdly, there are serious issues regarding leadership. And fourthly and finally, the world is witnessing the emergence of new powers, namely in China, India and Brazil. Stephens (2009) uses the phrase "the crunching and gridding of geopolitical plates" for all the above-mentioned changes and all the new actors emerging on the global scene. Adding to this, we may add the hosting of the Olympic Games which has shifted from the West to the emerging states.

However, one might ask which states can actually be called emerging powers? According to Cooper and Flemes (2013: 945), several countries 
can be perceived as such, as there is no precise definition of countries within this club. Therefore, different acronyms are both used and contested, such as BRIC 1 , BRICS ${ }^{2}, \mathrm{BASIC}^{3}$, and BRICSAM ${ }^{4}$. In this article, the $B R I C S$ states are being referred to as the emerging powers.

We understand globalisation as a concept which captures complex interrelations between the local and the global introduced and explained among others by Brannagan and Giulianotti (2015: 705) with the concept of 'glocalisation' and 'glocal consciousness', which refers to "how nationstates position themselves vis-a vis processes of globalization". This is particularly evident from using Olympic diplomacy by emerging states in order to change their international image, strengthen their national identity, or to position themselves on the global stage, which will be further addressed in the article.

In many cases, hosting the Games is perceived as a strategy relying on soft power. However, Nye's concept, applied to the case of the US is challenging to apply to all other cases. Namely, the results of soft power strategy often take much longer and its instruments are not fully under the control of governments (Nye in Cooper et al. 2013: 568). According to Shambaugh (2013) "soft power is not created by investing billions in global sports events. It is not a tool than can be purchased in a World Politics Shop". In the article, we use Nye's concept of soft power to understand emerging states' Olympic diplomacy and the attempts to increase their role in multipolar international relations, through hosting and participating at the Olympic Games.

One of the ways that governments wield soft power is through sport diplomacy, mostly manifested as public, indirect diplomacy. It is developed to communicate with the publics of other countries in order to influence their governments indirectly. Emerging states use its subcategory (Olympic diplomacy) in order to win the bid for hosting the Olympic Games. However, no universal definition of sport diplomacy

\footnotetext{
BRIC consists of Brazil, Russia, India and China.

2 South Africa formally joined with Brazil, Russia, India and China to create BRICS at a summit in 2011.

3 Became known in the context of the Copenhagen Conference of Climate Change Control (negotiations with the United States). Consist of Brazil, South Africa, India and China.

4 Refers to five most important emerging economies, known as the O5 (Outreach 5): China, Mexico, India, Brazil and South Africa.
} 
exists, where some scholars consider it as subcultural diplomacy, while others think of it as public diplomacy influencing the mass audience and creating the image of the state. We define sport diplomacy as a range of formal and informal actions focused at implementing foreign policy through sport. For instance, this could mean to either endorse or condemn large sporting events; to strengthen nationalist sentiments; develop or refine the concepts of nation-states and national identities; but also, to communicate political messages, promote dialogue and encourage integration within multicultural societies (Luša in Jović 2016: 229-283). The term Olympic diplomacy is usually equated with the term sport diplomacy and referring to the diplomatic role and policies of the IOC. In this article we approach Olympic diplomacy from the unit level, defining it as an effort made by states to win the bid for hosting and successfully participating at the Games; to promote historical and cultural heritage before, after and especially during the Games; to raise their significance and power in international relations by scoring the greatest results; and by, winning as many medals as possible, as well as to achieve economic benefits from hosting the Games.

\section{The Olympic Games as the intersection of nationalism, globalization and universal values}

Debates about the nation-states and globalisation are very common in IR literature (Berger; 2001, Reis 2004; Smith 2001). Anderson (2006: 3) argues that "nation-ness is the most universally-legitimate value in the political life of our time" while globalists "underline the weakening of the territorial boundaries of nation-states due to the certain economic, political and social forces being able to elude nation-state control". Concepts of nationalism and globalisation are themselves being disputed. Some scholars even reject the globalisation paradigm. Bairner (2001: 5-6), on the contrary, argues that: "we live in a post-national world in which distinctive identities based on the idea of nation are being eroded and an everincreasing homogenization is occurring". 
The area in which nationalism and globalisation are much-discussed concepts is the study of sport. Therefore, this section of the article investigates the extent to which hosting of the Olympic Games can be used for the strengthening of national identity and the expression of nationalism by the emerging states in the context of globalisation. Namely, one cannot disconnect nationalism from competition, as the basis of the Olympic Games is built on the premise of nation-states and national organisations, while also underscoring the ethos of the Games as human unity (Malia 2014: 3).

Allison (in Allison 2005: 2) argues that: "there is a global system of cores and peripheries in which leading sportsmen from peripheries rarely play in their country of origin", which indicates interrelation between globalisation and sport. Furthermore, in the capital market, different nationals and interest groups become owners of national sporting clubs. The Olympics, according to Tomlinson (in Allison 2005: 45) operate "as a giant billboard for the elite crop of multi-national corporations that are the preferred sponsorship partners of the IOC." "This serves the interest of five simultaneous processes, which characterize the present moment in sport: globalization, governmentalization, Americanization, televisualization and commodification" (Miller et al. 2001: 41). These economic, political and cultural dimensions' intermesh in phenomena such as the Olympics symbolising the strengths of globalisation.

Good showcases of globalisation in sports are Michael Phelps 5 , Serena Williams ${ }^{6}$, Roger Federer ${ }^{7}$ and Usain Bolt ${ }^{8}$, who are cheered for around the globe, because of their extraordinary sporting results. At the Olympic Games in Rio 2016, universal human values were additionally shared with heart-warming images of the Olympic Refugees Team competing in recognition of the 60 million refugees around the world. A great example of the Olympic spirit was also a scene during the qualifying heat of the women's 5000 meters, when New Zealand and American runners Nikki Hambin and Abbey D'Agostino "set aside their own hopes and national

5 Michael Phelps is an American swimmer who won the most Olympic medals in history.

6 Serena Williams is an American tennis player who occupies 2nd place in number of Grand Slams won in the Open Era.

7 Roger Federer is a Swiss tennis player who won 19 Grand Slam single titles, the most in history. Among other achievements he holds a record of 302 weeks being the number one on the ATP rankings list.

8 Usain Bolt is a Jamaican sprinter and a nine-time Olympic gold medalist. In 2016 he became the first track athlete in modern Olympics to win gold medals in two individual disciplines at three consecutive Olympic games, which he achieved in the $100 \mathrm{~m}$ and $200 \mathrm{~m}$ sprint. 
interests of making the finals to look out for a fellow competitor" (Imray 2016). They have been praised for embodying the Olympic spirit (Roy 2016). This proves the universal spirit of the Olympic Games, which is additionally strengthened by Maguire (2009: 5-6), who argues that "given the growth in the multiplicity of linkages that transcend the nation-states, we may be at the earliest stages of the development of a "transnational culture" or a "global culture". Koorep (2016:17) takes the view that "the mega sporting events provide us with a magnifying glass on the process of globalization".

To summarize: firstly, globalisation in sport is a reality, due to virtually omnipresent modes of communication. Around 342 million people watched the opening ceremony of the Rio Games in 2016, while the Beijing opening had more than 1 billion viewers (Roxborough 2016). Secondly, the rules of the game are understood by almost everyone. Thirdly, global sports present an excellent equaliser from the equal opportunities perspective. Namely, sport is supposed to be available to everyone, at least its basic forms or its amateur level (Marmolejo 2012). These arguments speak in favour of globalisation being very much present in sport.

On the other hand, nationalism, national interests and the role of a nation-state present driving forces for using Olympic diplomacy as a soft-power tool by emerging states. Furthermore, different interest groups use the Olympics to promote their goals. At the very beginning, one of the fundamental principles of the modern Olympics, developed by Baron Pierre de Coubertin, and embedded in the Olympic Charter, was the prohibition of any forms of propaganda or advertising related to any political, religious or racial issues. However, this policy has changed meaning and it is now quite easy to use the Olympic idea to manipulate the public mood (Luša in Jović 2016: 229-283). In the case of the emerging host states there are certain groups using the Olympic Games, which in themselves are highly politicised, and reflect the global political situation, to fight their battles. Russia is an example in which activists put a spotlight on the disrespect for human rights and media freedoms and called for boycotting the Sochi Winter Olympic Games in 2014 (Sorkonin 2013). The Beijing Olympic games were also encountered with several calls for boycotts organised by different organisations such as the International Campaign for Tibet, Students for a Free Tibet, as well as by many prominent 
political and media figures. Bittnerová (2009: 10) distinguishes two types of pressures host countries can be put under: one being tactical, referring to attention drawn away from sports to any domestic and international issues, and the other being ideational by calling upon often authoritarian regime for differences between itself and the Olympic values. For example, the Brazilians, during their political turmoil', wanted to use the Games to highlight their grievances, but both the Olympic Committee and Brazil's government warned that political acts are not allowed inside Olympic venues (Garcia-Navarrro 2016).

Although the Olympics have been conceived to promote unity, cooperation and global understanding, except from particular groups and movements fighting for their cause, the emerging host states use Olympic diplomacy to promote different national agendas on the world stage. Namely, the Olympics present a tension between the joy of participation and the competition between representatives of nations.

Even though the existence of organisations such as the IOC (International Olympic Committee) shows some kind of the supranational governance of sport, nation-states remain important with international competitions organised around national teams. According to Large (2016), "the games succeeded because they indulge precisely what they claim to transcend - the world's basest instinct for tribalism." Going back to the past one can notice that in authoritarian states where the Government had direct control over sport (Soviet Union, Germany, Italy and Spain), sporting competitions were therefore "circumscribed by political considerations that often transformed purely sporting contests into other rivalries: communism $\vee$. capitalism, fascism $v$. liberal democracy, communism v. social democracy" (Riordan 2003: 1). In the 1930s, sports played the most important role in shaping of Italian national glory abroad (Gordon and London 2006: 41-65), while the Berlin Olympics were the most controversial games even during the bidding process. As for the Cold War period, sport became an alternative means of competition between Americans representing liberal democracy and the free market, and the Soviets representing communism (Kobierecki 2013: 55). When the domination of the Soviet Union and other communist countries became more evident

9 "Dilma Rousseff, Brazil's elected president has been suspended and was awaiting an impeachment trial in the Senate for fiscal mismanagement" (Garcia-Navarrro 2016). 
in the 1960s, Americans realised that sport is a matter of international prestige and went on to win the most medals in the 1964 and 1968 Olympic Games. The situation changed again in favour of the Eastern bloc in the 1970's, while the 1980's can be called the era of sports boycotts (ibid.: 58). Medal counting and competition between two confronting blocks prove how the Games were misused for political purposes and for promoting national interests during the Cold War (Luša in Jović 2016: 229-283).

The use of Olympic diplomacy by the host emerging states, aiming to reinforce national sentiment, national ideas and identities, which proves sport is never detached from the concept of nation, is particularly vivid. We claim that Olympic Games hosted by China, Brazil and Russia point at the heterogeneous side of globalisation, where Olympic diplomacy is used as a soft power tool to promote national interests. A country's initial ambition is to participate at the Olympic Games, which is followed by the incentive to host the Games and finally to win more medals to become a leading Olympic power.

\section{Olympic diplomacy at the Beijing, Sochi and Rio Olympic Games}

With the slogan "One World, One Dream" symbolizing the Chinese renaissance and the harmonisation of the world civilisation, China, which hosted the Olympics in 2008 (Beijing), attempted to mark its integration in the international community (Müller and Steyaert in Munoz 2013: 141). However, it used the Games to underscore exceptionalism, to restore the pride in its tradition and promote a set of ideas that would appeal also to states disconnected from the Western dominance. The process of organising the Games for China had to balance between international openness and nationalist tendencies. It was also supposed to create the perception of contemporary China as a world power without being labelled as "the sick man of East Asia" (Tan and Houlihan 2013: 134). Athletes and coaches were dispatched abroad, aiming to improve their performance and skills, simultaneously with welcoming foreign coaches to 
bring new knowledge and resources. ${ }^{10} \mathrm{XU}$ (2006: 92) argues that "sport has been another frontier of New China's struggle for international legitimacy and prestige".

After the 2008 Summer Olympic Games had been awarded to China, the relationship between the Games, patriotism, national unity and modernisation has constantly been highlighted. "The passion of the Chinese nation, the excitement and the feeling of pride erupted like a volcano" (Fan et al. 2011: 35). Beijing's two bids"1 for the Olympics reflected its strong economic development and its increasingly important role on the international political stage. The hosting of the Olympics signalled China's position not only outwardly but also within the country's borders, in its efforts to unify the people and strengthen national identity. Therefore, "a key success of the Beijing Games was in fostering Chinese nationalism" (Polson and Whiteside 2016: 3089 -3090). During the bidding process for the Olympic Games to be held in 2008, China relied on different Olympic diplomacy strategies such as publicising the bid nationally and internationally, campaigning worldwide, and investing heavily in their athletes who were supposed to "convince everybody about China's modernity and international recognition" (Bitternová 2009:26) .

The most important showcase of the use of Olympic diplomacy as a soft powertool was seen at the opening ceremony aimed at presenting Chinese rich history and its success to the world. It was used to represent China as modern and innovative: to strengthen the correlation between athletic triumph and China's status as an emerging state, as well as to improve its media communication skills (Jianping 2008:6). Olympic diplomacy was focused on showing China's economic advancement by promoting a "High Tech" Olympics, in portraying China as politically stable and orderly, in asserting China's achievement of international respectability and in addressing environmental issues by promoting a "Green Olympics". The third concept of the Games was "People Olympics" (deLisle in Price and Dyan 2008: 19-29).

10 Zhang, China's first male champion swimmer who has been training in Australia. This strategy resulted in winning a silver medal at the 2008 Beijing Olympic Games in the men's 400m freestyle and in 2009 he was crowned the world champion at the Rome World Championships (Lei 2011). Among 711 sportsmen travelling to Rio, 29 foreign names drew attention (Youming 2016).

11 After losing its first bid to Sydney in 1993, Beijing won its second bid in 2001. In 1990, China hosted 11th Asia Games as the first major international sporting event on its soil. Despite the strong use of the Olympic diplomacy to win support for the hosting of the Games in 2000, China failed which led to "the first explosion of the Chinese nationalism in the reform era (Fan et al. 2011:33). The other cities were Toronto, Paris Istanbul and Osaka. 
Except from serving these foreign policy goals, Olympic diplomacy was also used to consolidate China's nationalism resulting with the government gaining more popularity and support, or by convincing the domestic audience of its legitimacy legitimacy. After China re-joined the Olympic movement in the 1970's, it participated at nine summer Olympic games, with the Beijing games presented as the most successful one (Li et al. 2007: 3). Its overall medal rankings ranged from eleventh place in Seoul in 1988 to first place in Beijing in 2008. The games it hosted were also the one at which China participated with the highest number of athletes in its Olympic history. China won 100 medals in Beijing in comparison to 63 in Athens in 2004 (Olympic.cn 2017). This brought official triumphalism and strengthened China's status as a rising sports power. The feelings of superiority advanced by the sporting success is associated with nationalism as the form of national identification.

On the other hand, the narrative of a globalised China was promoted particularly with the slogan "One World, One Dream", signalising cosmopolitanism, harmony and universality. The slogan was used to reassure the world that China, which showed its power in organising a spectacular mega event, is not a threatening China (Rosner 2009: 10). There were also several foreign-designed architectural interventions and projects, as well as contributions by Chinese celebrities, which supported the cosmopolitan theme of the Games. These narratives served to emphasise China's "deep engagement with the outside world" (delisle in Price and Dyan 2008: 30).

The heterogeneous side of globalisation and the urge to promote national interests is also demonstrated in the case of Russia as the host of the Winter Olympic Games in Sochi in 2014. In July 2007 Russia was awarded the Games ${ }^{12}$ with the opportunity for the country's return to "great power status" (Foxall 2015: 622). Putin's Federal Target Program for the Development of Sochi as a Mountain Climate Resort in 2006-2014, as the priority of the Russian government in 2006, presented a part of overall Russian Olympic Diplomacy (Petersson and Vamling 2013: 7). According to Müller (2011: 2095), the Sochi Games have been characterised as Putin's "pet idea" with the Games having a twofold purpose: using Olympic diplomacy "to send a signal of strength and pride" to Russia's international 
audience, legitimising Putin's rule, and showing Russia as a strong global player (Haus 2014). Russia decided to focus the opening ceremony on its contribution to universal values, literature and music, while simultaneously highlighting its power. This was done by showing the most progressive actors and stabilising events from its history (Gorenburg 2014). Additionally, the recent scandalous revelations of alleged state involvement in doping cover-ups at the Sochi 2014 Olympic Games and the suspension of Russian athletes from the Rio Olympics, reaffirm that sport, national interests and the Olympic Games are connected. According to Ford (2014) "the outcome of the Olympics has always had implications for national prestige, especially for Russia "whose Olympic success has risen and fallen in step with its changing geopolitical fortune" (Ford 2014). Instead, the Sochi Games not only affirmed Putin's popular status but worked to legitimise his government (Munt 2015: 42). This strong effort is evident from the fact that Russia participated at the Games with 232 athletes winning 33 medals and ending up in first place, which is the same result achieved at the Olympics held in 1994 in Lillehammer (Olympic.it 2017).

Adding further to the argument of emerging states' use of Olympic diplomacy to promote their national interests, one can notice that the hosting of the Olympic Games in 2016 and the FIFA World Cup in 2014 influenced the strengthening of Brazil's soft power. Therefore, the Olympic Games were fully endorsed by the national government and supported by, at the time, president Luiz Inácio Lula da Silva, who stated that "with the Olympics Brazil gained its international citizenship and that the world has finally recognized it is Brazil's time" (Horne and Silvestre in Bainer et al. 2016: 490). Therefore, the Brazilians realised the importance of hosting mega sporting events and have been using it as a very important tool of their foreign policy. Brazil's role as the host country of two international mega sporting events gave it a chance to show itself to the world in a different light. However, due to the unfolding political turmoil, economic decline, a rise in armed violence, mounting environmental problems, the Zika virus health crisis, and the surge in social grievances against widespread inequality and public corruption, "Brazil's position as host nation was historically perilous" (BBC.com 2016). On the other hand, Brazil had a lot to offer as a model for positive social relationships in matters of race and inclusiveness, and as a country full of stories of inclusion and struggling democracy. 
Brazil's Olympic diplomacy dates from the beginnings of the Modern Olympics and from always being represented at the IOC. The bidding for the Olympic Games in 2016 marked Brazil's fifth attempt, but for the first time it went to the second round (Almeida et al. 2014). The success of Brazil is also evident from the overall Rio games medal table, according to which it participated with its historical record of 465 athletes and occupied $13^{\text {th }}$ place with 19 medals won. The worst ranking for Brazil was recorded during the Sydney Olympic Games in 2000 (52 ${ }^{\text {nd }}$ place) (Olympic.it 2017).

Aforementioned experiences from using Olympic diplomacy and hosting the Games highlight the role of the nation-state and the opportunity given to emerging countries to use sport as a tool for promoting their national interests, national identity, and in most cases, to display their nationalism. It confirms the role of sports in supporting a state-centric approach. From the comprehensive analysis presented here, one can see the Olympic Games as an intersection of nationalism, globalisation, and universal values. Therefore, we can conclude that as much as sport contributes to the unifying process of globalisation, it also strengthens the concept of nation by promoting national identities and interests.

\section{Multipolarity, emerging states and hosting the Olympic Games}

The hosting of the Games represents great prestige, given that 29 Summer Games have been held in just 19 countries, and 22 Winter Games have been hosted by a total of 11 countries (seven of which also hosted the Summer Games). In 121 years, ending with the Summer Olympic Games held in Brazil in 2016, 45 out of 51 Olympics were organised in Europe, North and Central America and Australia.

Pierre de Coubertin, founder of the modern Olympic Games, saw them as a tool to overcome social inequalities, and a way for economically disadvantaged people to access sport. However, despite his intentions, "the Games have been dominated by a handful of states and by Euro- 
centrism" (IPSA.org 2016). Furthermore, in terms of hosting these events - producing and marketing the sports equipment, controlling the sports federations or relevant decision-making - it is the West that dominates. There is a belief, among western politicians and bureaucrats, "that the Games should go only to countries that conform to western ideals of democracy and human rights" (Brownell 2014).

After London 2012, the Olympic Games are or will be hosted outside the "Western world" (The South American continent hosted its first Olympics in Rio de Janeiro in 2016, while the next three Olympics hosts are located in Asia: Pyeongchang in 2018, Tokyo in 2020 and Beijing in 2022) ${ }^{13}$, which confirms our understanding of sport as a reflection of multipolar international relations. According to Kelly (in Kelly and Brownell 2011:7) "from Greece (the front of Western civilization) to China (the cradle of Asian civilisation), the Olympics were finally transiting from parochialism of its Eurocentric philosophy to a more truly global philosophical foundation." This trend raises the question of whether sport is influenced by geopolitics and geoeconomics, and follows the shifting of the international system towards multipolarity.

We argue that emerging countries with their Olympic diplomacy managed to position themselves as core nations, at least during the Games, having in mind that the Olympics illustrate the power of a nation. Furthermore, the shift of Olympic Games hosts symbolises a form of multipolarity in sports, emerging as multipolarity in politics that is setting in. China, South Africa and Brazil (members of the BRICS) have managed to become the hosts of Olympic Games and FIFA World Cups, which signals their respective arrival as credible powers. At the same time, it demonstrates "the new order of things not only in international sports, but also in the international system" (Grix and Lee 2013). Even during the Summit of the BRISC in 2011 the future cooperation was, among other, conditioned by organising successful Olympic Games and World Cups in Russia and Brasil (IPSA.org 2016). Global shifts are also evident from the fact that "SovietAmerican duopoly gave way to Sino-American duopoly" in winning medals at the Olympic (16\% of all medals won in Sydney, $17 \%$ in Athens,

13 Except from hosting there is also an evident increase of non-traditional western powers biding for the Summer Games: China, Turkey, Brazil and Uzbekistan for the 2000 Games; Argentina, South Africa, Turkey, Brazil, Russia and Puerto Rico for the 2004 Games; Turkey, Japan, Cuba, Egypt, Malaysia and Thailand for the 2008 Games; Russia, Cuba, Turkey and Brazil for the 2012 Games; Japan, Qatar, Czech Republic and Azerbaijan for the 2016 Games; Qatar, Turkey and Azerbaijan for the 2022 Games (Wikipedia.org 2017). 
$22 \%$ in Beijing, $20 \%$ in London and $19 \%$ in Rio). However, India presents the greatest counter-example in showing that political multipolarity and sports multipolarity are "cast from the same mould". Furthermore, Russia and China are the only BRICS countries represented at the top 10 medal winner list from 2000 onwards.

Confirming the influence of political shifts in sport, Pound (2004: 198199) argues that for some members of the IOC the starting point for deciding on the host city are geopolitical considerations. There is always a vivid discussion whether the country was selected only because of its achievements, or if it was perceived as a part of the wider region. According to Wallerstein (2009), "there is a geopolitical rationale behind the decision, which favored Brazil as a representative of the South". Brazil hosted the 2007 Pan American Cup, the 2014 FIFA World Cup, as well as the 2016 Olympic Games, almost 50 years after Mexico City hosted the Games in 1968. This serves not just as the announcement of its readiness to join the advanced Western capitalist states, but "to indicate its shift from a regional actor to a global actor in international affairs" (Grix and Lee 2013: 14). There are always disputes whether the host country also presents a wider region. Brazil, with the significant power, acted as a "rare island of stability in a region of turmoil" (Fendrick 2013: 25). Its significance was also reaffirmed by the IOC statement that the bid for the 2016 Games "was not only national, but also of South America, a continent that never hosted the Games" (Almeida et al. 2014).

Another case of multipolar trends is Beijing hosting the Games. According to Grix and Lee (2013: 12), "China's Olympics could be read as an attempt to present the nation that has shifted from being a regional superpower to a global power". Breslin (2013: 623) argues that "China has become a more active and involved actor in global affairs not attempting to be part of a core, occupied by advanced capitalist states, but rather an emerging, alternative power to those in the West." "Unlike Brazil, which called forth message of both regional and national development, China was in it for the good of China" (Fendrick 2013: 34). However, according to some authors, the Beijing Games also had regional significance and were used "to bring an Asian dimension to the Olympics" (Kelly in Kelly and Brownell 2011: 2), by presenting only the fifth games held in Asia (Tokyo 1964, Sapporo 1972, Nagano 1998, Seoul 1988 and Beijing 2008). 
Finally, the Sochi Games were "all about Russia's return to power and more indicative of a post- Cold War rise of Russia, than it is of regional development" (Fendrick 2013:30).

Although the five rings represent the continents participating at the games, Africa is still a blank space on the Olympic hosting map. Developing countries have been excluded and marginalised from hosting the Games, through a very expensive bidding and hosting process and the role of geopolitics, although the Olympic ideal promotes sport as being available to all people on all continents.

Developing countries, especially those in sub-Saharan Africa, must overcome many challenges to reach their goal of hosting the Games. The known African bids for the Olympics are South Africa for 2004, Egypt for 2008, while South Africa and Kenya announced their bids for 2024 (Fendrick 2013: 51). According to the Olympic Charter, the IOC was supposed to suspend any discrimination policies, a responsibility it failed to uphold to developing countries. Therefore, we argue that sporting events conceal the geopolitical "standings" of the host nation. This view is confirmed by Immanuel Wallerstein (2009), who found that "geopolitics has never been absent from the games."

Going into the past, one can find interesting data about developed countries exclusively hosting the Summer and Winter Games from 1928 through 1964. With the exclusion of Mexico in 1968, Beijing in 2008 and Rio in 2016, all other Olympic Games were hosted by developed rich Western countries (the same goes for the Winter Games if Russia and the former Yugoslavia were categorised as emerging economies) (Baade and Matheson 2015: 3). However, from 2008 BRICS countries hosted or will host four Games. What these countries have in common, despite their many differences, is that they have all become emerging players in multipolar international relations. 


\section{Conclusion}

The three case-studies presented in this article clearly show that except from the unifying pattern, the Olympic Games are also a reflection of particular national interests and the strive for power, especially among emerging states. The appearance of some of the BRICS states as Olympic host nations follows the shift to multipolarity as evident within international relations.

One of the reasons behind this trend, except from particular national interest, geopolitics and emerging new powers on the global stage, are the interest groups in search of new markets and the role of geoeconomics.

Firstly, the cost of the Games presents the main argument why they are moving away from the developed West. Having in mind that a city's nor a country's government "receives no direct revenues from hosting the Olympics, the financial revenues must come from a Games-generated economic boost and increased tourism "(Koorep 2016: 33). Therefore, developed countries, which already have high-income economies have very little to win from hosting the Games.

Secondly, the Olympic hosting costs for BRICS countries, where resources are scarce and the fiscal balance more fragile are far greater. Scholars analysing the economics of hosting sporting mega-events warn "that such events fail to deliver the 'economic bonanza' promised by the event organisers, and that the benefits and costs are disproportionally shared" (Baade and Matheson 2015: 1). However, with each bidder trying to outdo the others, expenditures increased (Zimbalist 2015: 1).

Thirdly, there is the new market hypothesis. The hosting of mega-events presents an intensified competition for public attention and investment. Companies strive to associate themselves with the Games, in an effort to gain access to new markets with high profit potential. Therefore, a part of the rationale behind the choice for the Olympic Games' hosts is the geopolitics of expanding markets (Müller and Steyaert in Munoz 2013: 139140), with India, China and Brazil being among the four largest economies 
by 2030 (Grix and Lee 2013: 14). There are also corporate sponsors, who see the interest in their involvement in financing mega-events by selling products and reaching the largest potential market. According to Baade and Matheson (2015: 7), the global audience for the Summer Olympics is around 3.2 billion people. It is why a conclusion can be made that "multinational sponsors now want to target the emerging economies around the world rather than battling over one or two market share points in the oversaturated west" (Gibson 2010). Therefore, BRICS as the engine of the global market, represents a fertile ground for sponsors (Kirillov 2008: 38).

Fourthly, the bidding countries' nominal GDP might be considered as a factor, as well. Economic development was the idea behind the BRICS countries' desire to host the Olympics, the World Cup or the Commonwealth Games. Together, BRICS "hold more than $40 \%$ of the world's population and about $20 \%$ of the world's GDP" (Menhart 2016). Curi et al. (2011) argue that a "BRICS-style of hosting sports mega-events may be emerging". ${ }^{14}$ These states "have shown that they are not backward or incompetent, thereby challenging the developed states" (Fendrick 2013: 25).

According to the analysis presented in this paper, it is evident that the world of sports is a reflection of the world of politics. It is becoming multipolar, with emerging countries hosting mega sporting events. Most of these countries use such events to announce their arrival on the world stage as global players. Although the hegemonic control of sports still remains with the Western world, which is trying to impose a consumption of narrow capitalist and Western sports culture, this has not led to a complete homogenisation. The Olympic Games still contribute to the heterogeneous side of globalisation, with non-Western states reinforcing national identities and promoting their own values and interests on a global scale. Globalisation has not flattened the world and we can still see a far-reaching contribution of Olympic diplomacy to nation-building and national pride.

There are evident differences between emerging countries in terms of hosting the Games, as well as other parameters, which are decisive

14 Beijing hosted the Olympic Games in 2008, Delhi the Commonwealth Games in 2010, South Africa the FIFA World Cup in 2010, Russia the Winter Olympic Games in 2013 and the FIFA World Cup in 2018, and Brazil the Pan American Games in 2007, the FIFA World Cup in 2014 and the Olympics in 2016. 
for the shifting trends in the world of sports. Except for the geopolitical dimension of selecting the host country by recognising the hierarchy of the IOC as the supreme authority in all matters related to the Games (as well as the state of world politics), there is also a geo-economic dimension. This includes broadcast revenues and corporate sponsorships that acknowledge the capacity of sports to attract large audiences. These, along with the membership structure of the IOC, profit oriented sponsors, and other particular interests demonstrate the interconnection between geo-economics and the world of sports.

Finally, in many cases, hosting the Games is perceived as an Olympic diplomacy strategy and a soft power tool. Nations and cities seek to host the Games with the expectation that it will significantly boost their economies. However, scholars seem to agree that the benefits of hosting are generally not substantial enough to ensure an economic shift. ${ }^{15}$ The payoff might be realised only in the long run. According to Zimbalist (2015) "the main legacy consists of white elephants that cost billions to build and millions annually to maintain, along with mountains of debt that must be paid back over ten to thirty years."

15 Of the $\$ 3.85$ billion from television rights in the period from 2009-2012, 56 percent came from the U.S. right fees. It is striking that the IOC does not share a large portion of the generated revenue with the Organizing Committee (less than 50 percent of the TV revenue) (Zimbalist 2015). 


\section{Bibliography}

Allison, L. ed., 1986. The Politics of Sport. Manchester: Manchester University Press.

Allison, L., 1993. The Changing Politics of Sport. Manchester: Manchester University Press.

Allison, L., 2005. Sport and globalisation. In: Allison, L. ed. The Global Politics of Sport. The role of global institutions in sport. London and New York: Routledge. pp. 1-5.

Almeida, B. S., Marchi, W. and Pike, E., 2014. The 2016 Olympic and Paraolympic Games and Brazil's Soft Power. Journal of the Academy of Social Sciences, 9(2). [pdf]. Available at: http:// eprints.chi.ac.uk/2312/1/Almeida\%20Marchi\%20and\%20Pike.pdf (Accessed 1 August 2017).

Anderson, B., 2006. Imagined communities: Reflections on the origin and spread of nationalism. London: Verso.

Arnaud, P. and Riordan, J. eds., 1998. Sports and International Politics. The Impact of Fascism and Communism on Sport. London \& New York: E\&FN Spon.

Baade, R. and Matheson, V., 2015. An Analysis of Drivers of mega-Events in Emerging Economies. College of the Holy Cross, Department of Economics, Faculty Research Series, Paper No. 15-07.

Bairner, A., 2001. Sport, Nationalism and Globalisation. European and North American Perspectives. Albany: University of New York Press.

Berger, M., 2001. The nation-state and the challenge of global capitalism. Third World Quarterly, 22(6): 889-907.

Wikipedia, 2017. Bids for the Olympic Games. [pdf]. Available at: https:// en.wikipedia.org/wiki/Bids_for_Olympic_Games (Accessed 16 June 2017).

Bittnerová, A., 2009. The Olympic Games as a Political Tool: Case Study Beijing 2008. Bachelor thesis. Masaryk University, [online]. 
Available at: https://is.muni.cz/th/39771 1/fss_b/Bakalarska_prace_ Bittnerova_Andrea_397711.pdf (Accessed 20 July 2017).

Brannagan, P. M. and Giulianotti, R., 2015. Soft power and soft disempowerment: Qatar, global sport and football's 2022 World Cup finals. Leisure Studies, 34(6): 703-719.

Breslin. S., 2013. China and the global order: signaling threat or friendship? International Affairs, 89(3): 615-634.

Brownell, S., 2014. The Olympic Games and Asia's Rise. Yale Global Online, 27 November [online]. Available at: http://yaleglobal.yale.edu/ content/olympic-games-and-asia\%E2\%80\%99s-rise (Accessed 18 June 2016).

Brunet, F. and Xinwen, Z., 2008. The Economy of the Beijing Olympic Games: An Analysis of First Impacts and Prospects. The Centre d'Estudis Olímpics (CEO-UAB) [online]. Available at: http://citeseerx.ist.psu. edu/viewdoc/download?doi=10.1.1.517.1617\&rep=rep 1 \& type=p df (Accessed 20 July 2017).

Buzan, B., 2004. The United States and the Great Powers. World Politics in the Twenty-First Century. Cambridge: Polity Press.

Cooper, A. and Alexandroff, A., 2010. Introduction. In: Alexandroff, A. and Cooper, A. eds. Rising States, Rising Institution. D.C.: Brookings Institution Press. pp.1-17.

Cooper, A. and Flemes, D., 2013. Foreign Policy Strategies of Emerging Powers in a Multipolar World: an introductory review. Third World Quarterly, 34(6): 943-962.

Curi, M., Knijnik, J. and Mascarenhas, G., 2011.The Pan American Games in Rio de Janeiro 2007: Consequences of a sport mega-event on a BRIC country. International Review for the Sociology of Sport, 46(2): 140-156.

DeLisle, J., 2008. One World, Different Dreams. The Contest to Define the Beijing Olympics. In: Price, M. E and Dayan, D. eds. Owning the Olympics: Narratives of the New China. Ann Arbor: University of Michigan Press. pp.17-66.

Fan, W., Fan, H. and Zhouxiang, L., 2011. Why Did China Bid Twice for 
the Olympic Games? Sport, Nationalism and International Politics. Journal of Olympic History, 20(2): 31-37.

Fendrick, A., 2013. Why not Africa? An Exploration of the Correlation between International Sporting Events and Development. Undergraduate Honors Theses, Paper 347. University of Colorado at Boulder, [online]. Available at: http://scholar.colorado.edu/honr_ theses/347/ (Accessed 17 May 2016).

Ford, M., 2014. The Geopolitics of Winter Olympic Medal Counts. Can Russia reclaim its former Olympic glory? The Atlantic, 7 February [online]. Available at: http://www.theatlantic.com/international/ archive/2014/02/the-geopolitics-of-winter-olympic-medalcounts/283552/ (Accessed 16 June 2016).

Foxall, A., 2015. Geopolitics, Genocide and the Olympic Games: Sochi 2014. ACME: An International Journal of Critical Geographies, 14(2): 622-630.

Garcia-Navarro, L., 2016. Controversy Grows in Rio Over Political Protests During Olympics. NPR, [online]. Available at: http://www.npr.org/ sections/thetorch/2016/08/09/489284024/controversy-grows-in-rioover-political-protests-during-olympics (Accessed 10 August 2016).

Gibson, O., 2010. Commonwealth Games: More at stake than sport as India scrambles to salvage reputation: Hosting a successful games will alter the perception of Delhi around the world. The Guardian: Sports, 6, 3 September. (Accessed 13 August 2016).

Gordon, R. and London, J., 2006. Italy 1934: Football and Fascism. In: Tomlinson, A. and Young, C. eds. National Identity and Global Sports Events. Culture, Politics, and Spectacle in the Olympics and the Football World Cup. New York: State University of New York Press. pp. 41-65.

Gorenburg, D., 2014. The Sochi Olympics and Russian National Identity. PONARS Eurasia Policy Memo 316, [online]. Available at: http:// www.ponarseurasia.org/memo/sochi-olympics-and-russiannational-identity (Accessed 1 July 2016).

Gratius, S., 2008. The international arena and emerging powers: stabilizing 
or destabilizing forces? [pdf.]. Available at: http://fride.org/ download/com_emerging_powers_eng_abr08.pdf (Accessed 16 July 2016).

Gratton, C., Shibli, S. and Coleman, R., 2006. The economic impact of major sports events: a review of ten events in the UK. The Editorial Board of the Sociological Review, 54(2): 41-58.

Grix, J. and Lee, D., 2013. Soft power, Sports Mega-Events and Emerging States: The Lure of the Politics of Attraction. [online]. Available at: https://www.academia.edu/4475191/Soft_Power_Sports_ Mega_Events_and_Emerging_States_The_Lure_of_the_Politics_of_ Attraction (Accessed 30 August 2016).

Haus, S., 2014. The Putin Games. [online]. Available at: http://fpif.org/ putin-games/ (Accessed 25 July 2017).

Horne, J. and Silvestre, G., 2017. Brazil, Politics, the Olympics and the FIFA World Cup. In: Bainer, A., Kelly, J. and Jung, W. B. eds. Routledge Handbook of Sport and Politics. London: Routledge. pp. 483-496.

Houlihan, B., 2003. Sport and Society. London: Sage Publications.

Houlihan, B., 1994. Sport and International Politics. New York: Harvester Wheatsheaf.

Imray, G., 2016. Runners help each other after fall, lifting Olympic spirit. AP, [online]. Available at: http://bigstory.ap.org/article/035c72fd5ce6 4d10b50714e4d864287a/runners-help-each-other-after-fall-liftingolympic-spirit\%20(\%20Gerald\%20Imray (Accessed 26 August 2016).

Jianping, N., 2008. The Beijing Olympics and China's National Image Building. Draft Paper for the Workshop on China, the Olympics and the World. [pdf]. Available at: http://www.cctr.ust.hk/materials/ conference/workshop/14/nizp_olympics.pdf (Accessed 15 May 2017).

Kelly, W. W., 2011 . Introduction: Beijing 2008 and the Limits of Exceptionalism. In: Kelly, W. W. and Brownell, S. eds. The Olympics in East Asia. Nationalism, Regionalism and Globalism on the Centre Stage of World Sports. New Haven: Yale Univerity. pp. 5-19.

Kirillov, A., 2008. Annual State of the Industry: BRIC: It's Mighty, Mighty. CGI 
Magazine, June 2008.

Kobierecki, M., 2013. Sport in International Relations. Expectations, Possibilities and Effects. International Studies, 15(1): 49-74.

Koorep, R., 2016. Geopolitics of Sports Mega-Events: Why is International Sport Moving to Emerging Countries? MA Thesis. Faculty of Social Sciences, Johan Skytte Institute of Political Studies. [online]. Available at: https://dspace.ut.ee/bitstream/handle/10062/50579/ koorep_ranno_ma_2016.pdf?sequence=1 \&isAllowed=y (Accessed 1 June 2017).

Kurečić, P. and Kampmark, B., 2016. A Multifarious, Multifaceted Approach to the Multipolar World: A Necessity. In: Vrankic, I. and Tomas, D. eds. Economic and Social Development: Book of Proceedings. Koprivnica: University North. pp. 99-101.

Large, D. C., 2016. The Olympic Spirit is Unbridled, Rabid Nationalism. Foreign Policy, 12 August. [online]. Available at: http:// foreignpolicy.com/2016/08/12/the-olympic-spirit-is-unbridled-rabid nationalism/?utm_source=Sailthru\&utm_medium=email\&utm_ campaign=New\%20Campaign\&utm_term=\%2AEditors\%20Picks (Accessed 13 August 2016).

Lei, L., 2011. China's plan: send the best to the West. China Daily, 15 April, [online]. Available at: http://www.chinadaily.com.cn/cndy/201104/15/content_12330178.htm (Accessed 16 June 2016).

Levermore, R. and Budd, A. eds. 2004. Sport and International Relations: An Emerging Relationship. New York: Routledge.

Li, H., Meng, L. and Wang, Q., 2007. The Government's Role in China's Olympic Glory. [pdf]. Available at: http://www.sem.tsinghua. edu.cn/semcms_com_www/upload/article/image/2012_3/8_3/ fkayh5encroo.pdf (Accessed 14 April 2017).

Luša, Đ., 2016. Sport, politika i diplomacija: analiza iz konstruktivističke perpsektive. In: Jović, D. ed., 2016. Konstruktivističke teorije međunarodnih odnosa. Zagreb: Političke analize. pp. 229-283.

Maguire, J., 2009. Sport and Globalisation. Entry for:Sportand Development. Web-Based Platform, Swiss Academy for Development, Switzerland 
[pdf]. Available at: http://assets.sportanddev.org.sad.vm.iway.ch/ downloads/81_sport_and_globalisation.pdf (accessed 21 August 2016).

Malia, A., 2014. Reading the Olympic Games: nationalism, olympism, globalisation, and London 2012. PhD thesis, Loughborpugh University, [online]. Available at: https://dspace.lboro.ac.uk/ dspace-jspui/handle/2134/14880 (Accessed 15 July 2016).

Marmolejo, M., 2012. Globalization and the Olympics (Part I). [online]. Available at: http://www.understandglobalization. com/2012/07/26/globalization-and-the-olympics/ (Accessed 23 July 2016).

McBride, J., 2016. The Economics of Hosting the Olympic Games. CFR Backgrounders, [online]. Available at: http://www.cfr.org/brazil/ economics-hosting-olympic-games/p38148 (Accessed 5 August 2016).

Mearsheimer, J. J., 2001. The Tragedy of Great Power Politics. New York: W. W. Norton.

Menhart, M., 2016. Emerging Markets and the Olympic spirit - Citius, Altius, Fortius?, 5 August [online]. Available at: https://www.linkedin. com/pulse/emerging-markets-olympic-spirit-citius-altius-fortius?articleld=6167224564909637632 (accessed 21 August 2016).

Miller, T., Lawrence, G. A., McKay, J. and Rowe, D., 2001. Globalization and sport-Playing the world. London: Sage.

Monteiro, N. P., 2014. Theory of Unipolar Politics. Connecticut: Yale University.

Munt, V., 2015. Game, Set, Match: Sports and the Future of Diplomacy. CUNY Academic Works [pdf]. Available at: http://academicworks. cuny.edu/cgi/viewcontent.cgi? article=1557\&context=cc_etds_ theses (Accessed 5 June 2017).

Müller, M., 2011. State dirigisme in megaprojects: governing the 2014 Winter Olympics in Sochi. Environment and Planning A, 43(9): 20912108.

Müller, M. and Steyaert, C., 2013. The geopolitics of organizing mega- 
events. In: Munoz, J. M. S. ed. Handbook of the Geopolitics of Business. Northampton: Edward Elgar Publishing, Inc. pp. 139-150.

Nye, J. S., 2003. Hard, Soft and Smart Power. In: Cooper, A. F., Heine, J. and Thakur, R. eds. The Oxford Handbook of Modern Diplomacy. Oxford: Oxford University Press. pp. 559- 577.

Official Website of the Chinese Olympic Committee, 2017. Available at: http://www.olympic.cn/ (Accessed 1 August 2017).

Osada, M., Ojima, M., Kurachi, Y., Miura, K., Kawamoto, T., 2016. Economic Impact of Tokyo 2020 Olympic Games. BOJ Reports \& Research Papers [pdf]. Available at: https://www.boj.or.jp/en/research/brp/ ron_2016/data/ron160121b.pdf (Accessed 13 August 2016).

Petersson, B. and Vamling, K., 2013. Display window or tripwire? The Sochi winter games, the Russian great power ideal and the legitimacy of Vladimir Putin. Euxeinos, 12: 6-14.

Polson, E. and Whiteside, E., 2016. Getting in the Game? A Rising India and the Question of Global Sport. International Journal of Communication, 10: 3085-3105.

Pound, R., 2004. Inside the Olympics. Etobicoke, Ontario: J. Wiley\&Sons.

Preuss, H., 2004. The Economics of Staging the Olympics. A Comparison of the Games 1972-2008. Cheltenham: Edward Elgar.

Reis, E., 2004. The lasting marriage between nation and state despite globalization. International Political Science Review, 25(3): 251-257.

Riordan, J. and Krüger, A. eds., 1999. The International Politics of Sport in the Twentieth Century. London \& New York: E\&FN Spon.

Riordan, J., 2003. Introduction. In: Arnaud, P. and Riordan, J. eds. Sport and International Politics. London and New York: E\&FN SPON. pp. $1-3$.

Rosner, J. L., 2009. One World, Just a Dream? Effects of the Beijing Olympic Icon on Perceived Differences between Eastern and Western Culture. Master Thesis, Graduate College of the University of Illinois, [pdf]. Available at: http://citeseerx.ist.psu.edu/viewdoc/download ?doi=10.1.1.335.1628\&rep=rep 1 \&type=pdf (Accessed 6 June 2017). 
Roxborough, S., 2016. Rio Olympics Worldwide Audience to Top 3.5 Billion, IOC Estimates. The Hollywood Reporter, 18 August [online]. Available at: http://www.hollywoodreporter.com/news/rioolympics-worldwide-audience-top-920526 (Accessed 1 August 2017)

Roy, E. A., 2016. Olympic spirit: New Zealand and American runners help each other after collision. The Guardian, 17 August [online]. Available at: https://www.theguardian.com/sport/2016/aug/17/ olympic-spirit-new-zealand-and-american-runners-help-eachother-after-collision (Accessed 1 August 2017).

Shambaugh, D., 2013. China Goes Global: The Partial Power. Oxford: Oxford University Press.

Smith, A., 2001. Nationalism: Theory, Ideology, History. Cambridge: Polity Press.

Sorkonin, N., 2013. The effect of globalisation on Olympic Games. [online]. Available at: https://www.academia.edu/5193196/THE_EFFECT_ OF_GLOBALISATION_ON_OLYMPIC_GAMES.NIKITA-SOROKIN-NN (Accessed 3 August 2016).

Stephens, P., 2009. Four things you must know about the global puzzle. Financial Times, 24 September [online]. Available at: https:// www.ft.com/content/cc9abf6e-a93b-11 de-9b7f-00144feabdc0 (Accessed 24 July 2016).

Tan, T. C. and Houlihan, B., 2013. Chinese Olympic sport policy: Managing the impact of globalisation. International Review for the Sociology of Sport, 48(2): 131-152.

The Awarding of the Beijing 2008, Sochi 2014, and Rio de Janeiro 2016 Olympic Games as a Result of the Rise of the BRICS. [pdf]. Available at: http://paperroom.ipsa.org/papers/paper_7092.pdf (Accessed 20 June 2016).

Oxford Economics, 2012. The Economic Impact of London 2012 Olympic and Paralympic Games: A Report of Oxford Economics Commissioned by Lloyds Banking Group. July [pdf]. Available at: http://www.lloydsbankinggroup.com/globalassets/documents/ 
media/press-releases/lloyds-banking-group/2012/eco_impact_ report.pdf (Accessed 30 July 2016).

Toje, A., 2010. The tragedy of small power politics. The European Union under Multipolarity. Security Policy Library, 4. Oslo: The Norwegian Atlantic Committee.

Tomlinson, A., 2005. Olympic survivals. In: Allison, L. ed. The Global Politics of Sport. The role of global institutions in sport. London and New York: Routledge. pp. 42-57.

Youming, Y., 2016. Foreign coaches expected to add gloss to China's Rio Olympic delegation. Xinhuanet, [online]. Available at: http://www. xinhuanet.com/english/ (Accessed 25 July 2016).

Wallerstein, I., 2009. The Olympics and geopolitics. Commentary No.267. 15 October, [online]. Available at: http://iwallerstein.com/theolympics-and-geopolitics/ (Accessed 20 August 2016).

Xu, X., 2006. Modernizing China in the Olympic spotlight: China's national identity and the 2008 Beijing Olympiad. The Sociological Review, 54(2): 90-107.

Zimbalist, A., 2015. Circus Maximus. The Economic Gamble behind Hosting the Olympics and the World Cup. Washington D.C.: Brookings Institutions Press. 
Dana Luša (dana.lusa@fpzg.hr), PhD, is Assistant Professor at the Faculty of Political Science, University of Zagreb. Her primary fields of interests are foreign policy, in particular foreign policies of small European states, IR theory and diplomacy. From 2011 to 2016 she served as the Vice-director of the Postgraduate Study of Foreign Policy and Diplomacy, while currently she holds the position of Vice-dean for Science and International Cooperation. Her teaching experience includes courses in International Relations, Diplomacy and Transatlantic Relations at the undergraduate, graduate and postgraduate level. She actively participates at the most relevant international conferences in political science resulting with publications in international peer-reviewed journals. 